Article

\title{
Understanding Diver Behavior on Underwater Cultural Heritage: Enriching the Observation Record Using Video Methods
}

\author{
Joanne Edney $^{1, *(\mathbb{D})}$, Kay Dimmock ${ }^{2} \mathbb{D}$ and William E. Boyd ${ }^{3}(\mathbb{D}$ \\ 1 Office of the Deputy Vice Chancellor (Research), Southern Cross University, \\ East Lismore, NSW 2480, Australia \\ 2 Faculty of Business, Law and Arts, Southern Cross University, East Lismore, NSW 2480, Australia; \\ kay.dimmock@scu.edu.au \\ 3 Emeritus Faculty, Southern Cross University, East Lismore, NSW 2480, Australia; william.boyd@scu.edu.au \\ * Correspondence: joanne.edney@scu.edu.au
}

Citation: Edney, J.; Dimmock, K.; Boyd, W.E. Understanding Diver Behavior on Underwater Cultural Heritage: Enriching the Observation Record Using Video Methods. Sustainability 2021, 13, 5601. https://doi.org/10.3390/su13105601

Academic Editors: Marc A. Rosen, Brian Garrod and Nika Balomenou

Received: 7 April 2021

Accepted: 11 May 2021

Published: 17 May 2021

Publisher's Note: MDPI stays neutral with regard to jurisdictional claims in published maps and institutional affiliations.

Copyright: (c) 2021 by the authors. Licensee MDPI, Basel, Switzerland. This article is an open access article distributed under the terms and conditions of the Creative Commons Attribution (CC BY) license (https:/ / creativecommons.org/licenses/by/ $4.0 /)$.

\begin{abstract}
Successful underwater heritage management requires a sound understanding of visitor behavior. Primary visitors to underwater heritage sites are divers whose behavior can pose risks to the integrity of site cultural heritage and tourism values. This study seeks to understand wreck diver in-water behavior. Conventional observation of diver behavior is limiting. Wearable cameras are becoming popular across many recreational activities and potentially expand the scope and quality of diver observation. Video observation is rarely used in such research. This article demonstrates the potential of video observation, describing the analysis of first-person video records to explore details of diver behavior on shipwrecks. The evidence demonstrates that while most divers behaved responsibly, a few contributed to most contact behaviors. The analysis details this behavior, identifying, for example, that deliberate holding and touching comprised most contacts. Such findings on diver behavior inform heritage and tourism management decisions and provide a baseline for future studies. Methodologically, the study demonstrates the power of this method of observing divers and other recreationists. This is particularly valuable for researching recreationalists in confined spaces, such as caves or shipwrecks. The quality of results allows for further evidence-based examination of motivations, values, intentions and meanings underlying observed diver behavior.
\end{abstract}

Keywords: scuba diving; wreck diving; wearable camera; diver behavior; observational study; shipwrecks; management of underwater cultural heritage; Chuuk Lagoon; Federated States of Micronesia

\section{Introduction}

Successful underwater cultural heritage management requires a sound understanding of visitor behavior to effectively manage these unique resources, including negative impacts. The main visitors to underwater cultural heritage sites, including shipwrecks and submerged aircraft, are scuba divers. The use of these sites by divers can diminish their cultural heritage values [1,2], primarily through physical contact because disturbance to sites can alter site context and integrity and accelerate natural decay processes, such as corrosion and biodeterioration [3-6].

Understanding diver in-water behavior at underwater cultural heritage sites assists heritage and tourism managers to balance the demands of protecting cultural heritage and providing quality wreck diving experiences. Behaviors involving physical contact by the diver or their equipment with underwater cultural heritage are those most likely to adversely affect the cultural heritage values of underwater sites. Underwater cultural heritage sites are fragile, non-renewable finite resources that cannot be restored to their original condition or replaced and, unlike reefs, cannot regenerate once disturbed or damaged [7-9]. Controlling diver contact behaviors, therefore, sit at the core of such 
balanced management. Understanding broader diver behavior at underwater cultural heritage sites is also important, i.e., what divers spend most of their time engaged in, what aspects of the site they spend the most time looking at and what behaviors are most prevalent. Edney and Boyd [10] demonstrated the value of detailed observation of divers to benefit the development of appropriate underwater heritage management strategies. A key feature was the use of video observation, a technique rarely used in diver behavior research.

The aim of this study was to examine and critique wreck diver in-water behavior as a contribution to informing underwater cultural heritage and tourism management. The two study objectives were: (1) to identify diver contact and non-contact behaviors at shipwrecks and (2) to clarify the frequency of diver contact behaviors and durations of non-contact behaviors on shipwrecks. Quality evidence of in-water behavior is difficult to obtain; hence, a key central feature of this work is to apply an emerging technology, wearable video cameras.

\section{Literature Review}

\subsection{Recreational Scuba Divers and Underwater Cultural Heritage}

Recreational scuba diving became a reality in the mid-1940s, with equipment accessible to the general public [11]. The now multi-billion-dollar industry comprises an active and mobile community, and dive tourism forms an important part of global tourism that is significant to many local economies [11-14]. Commensurate with growth and maturation in dive tourism has been the increased demand for wreck diving. Wreck diving offers more challenging and diverse experiences, which divers often seek as skill and experience levels rise $[2,15]$.

Shipwrecks are important recreational and tourism resources. However, they are also important components of underwater cultural heritage due to their anthropological, archaeological, cultural, historic and social values. As noted above, shipwrecks are fragile, non-renewable and finite resources that cannot be replaced or restored to their original condition once disturbed or damaged [7-9,16].

Diver use of shipwreck sites can diminish heritage, recreation and tourism values. Growth in diver visitor numbers to shipwrecks has seen higher levels of impacts at sites visited by divers. These include impairment of site integrity and stability, unintentional and intentional contacts and the effects of exhaled air bubbles on wrecks (see $[1,2,17]$ for a detailed discussion of these impacts). Informed management of shipwreck sites is essential if cultural heritage, recreation and tourism values are to be protected from adverse human impacts $[2,14]$.

The literature specific to wreck divers is fledgling. It has primarily focused on wreck diver characteristics, motivations, preferences, attitudes and self-reported behavior. Studies include Holecek and Lothrop's $[18,19]$ work on wreck divers in the U.S. Great Lakes. More recently, there have been studies of wreck divers in the Federated States of Micronesia [20,21], research into Australian [21-24] and international wreck divers [1]. There remains, however, a lack of empirical studies of wreck diver actual in-water behavior in the global literature. Consequently, heritage and tourism managers are left to make decisions based on the assumed diver behavior and anecdotal information [1]. Knowledge of the actual behavior will enhance the effectiveness of management strategies for underwater heritage sites [2,14].

\subsection{Observational Research into Behavior}

Underwater environments are by their nature difficult places for making systematic and detailed observations of behavior. One option is for divers to self-report their behavior. However, self-reporting can be inaccurate and reports self-perception of behavior, not actual behavior. This limitation relates to influences including social desirability, comprehension, and accuracy of recall [25-27]. While the approach is useful in studying diver perceptions [1], studying actual behavior entails participant observation, which relies on the 
researcher's memory and the quality of recording methods [28-30]. The method requires accuracy of observation and observer ability to immediately appreciate the significance of behavior. The presence of an observer, and participants being aware of the research, can influence behavior, a phenomenon called the 'Hawthorne effect', 'observer effect' or 'reactivity' [31,32]. It may not be possible to entirely eliminate the observer effect, yet it is desirable if observations disrupt participation as little as possible [32,33].

The use of video to record diver behavior can benefit the researcher, providing a continual and non-interpreted record of divers and their environment. Video observation improves reliability, accuracy, trustworthiness and quality of data and data analysis. From an analytical perspective, data can be viewed, coded and analyzed repeatedly. The method is discrete and less distracting than traditional observation methods. It is, therefore, effective for observing behavior with minimal effect on that behavior [34-36]. The technology is inexpensive and widely available, including wearable cameras.

\subsection{Enhancing Diver Observation Using Wearable Cameras}

Wearable cameras offer innovative methods for social science research, capable of observing behavior previously not accessible. They are increasingly being used in health behavioral and ethnographic studies but appear underutilized in the social sciences more broadly [37-39]. Using wearable cameras to record participant behavior is particularly relevant to leisure activities because the images capture individual and personal experiences. Furthermore, since participants are already active, the camera need not interfere in the behavior. Modern wearable cameras, such as head-mounted cameras, are small and light, offering hands-free operation [34,40]. They provide a dynamic view of the participant's visual environment, are unobtrusive, and capture data over a period of time [41,42].

In the past 15 years, a plethora of small, robust and inexpensive wearable cameras became available; many can be head-mounted [34]. Papers are emerging in the tourism and leisure literature, which demonstrates the added knowledge to be gained from wearable cameras as a research tool. Previous studies using head-mounted cameras to observe tourism and leisure behavior that signifies experience include:

- The embodied experiences of walkers and mountain bikers in Cairngorms National Park (Scotland) [37].

- The bodily experience of walkers visiting Bowling Green National Park and Townsville Town Common (Australia) [43].

- The nature experience of hikers on the Appalachian Trail (USA) [41].

- The effect of human behavior on dolphins while snorkeling with wild Hawaiian spinner dolphins [44].

Wearable action cameras, in particular GoPro ${ }^{\circledR}$, have become commonplace amongst recreational scuba divers due to their small size, ability to be taken to $60 \mathrm{~m}$ depth, high video quality and ease of operation. They are used in various ways, including head-mounted. From a non-intrusive research perspective, divers are accustomed to GoPro ${ }^{\circledR}$ cameras and pay little, if any, attention to them. Participants get used to the camera presence and quickly forget them [37]. Pringle and Stewart-Evans [45], in a non-diving context, demonstrated no changed participant behavior from the camera's presence, and other studies contend the observer effect is overestimated [31,46].

There are some broad similarities between the methods used in Wiener's [44] study of the effects of human behavior on dolphins and this current study. Both studies are in a marine-based context, and both used head-mounted GoPro ${ }^{\circledR}$ cameras to gain a first-person perspective of human in-water behavior. Wiener's study used GoPro ${ }^{\circledR}$ cameras to record human movements (e.g., arm movements, use of camera, chasing) and resultant dolphin behavior. The study also employed third-person video and traditional observations of the participants to compare the behavior of participants and non-participants. Notably, no significant difference was found in the behavior of those wearing head-mounted cameras and those who did not. 
The ubiquity of GoPro cameras in recreational diving facilitates acceptance of this method of data collection because divers are accustomed to their presence. It allows video data to be collected by participants providing a first-person perspective and understanding of participants' visual environment, generating additional context (e.g., the behavior of guides and other divers) [47]. Such information may be difficult to extract from traditional researcher observations of participants, providing a substantial advantage of wearable cameras in research $[27,34,40]$.

\subsection{An Application of Wearable Cameras in Diver Behaviour Research}

Brown et al. [37] consider head-mounted video cameras suited to spatially constrictive, mobile and equipment-intensive activities-wreck diving meets these criteria, being situations where it is difficult to conduct observational research. Participants in the current study were scuba diving at sites where they could swim inside shipwrecks. This environment has low or no ambient light and confined spaces. In these situations, traditional observation methods would be difficult.

Diver safety was an important consideration in the methods used in this study. Scuba diving is equipment intensive, and divers need their hands free to operate the equipment. Using head-mounted cameras meant participants were not required to hold the camera, leaving them free to focus on diving, enhancing diver safety. Holding a camera can impact diver safety by impeding participants' ability to operate dive equipment and contribute to task loading. Task loading refers to competing for multiple tasks, for example, maintaining buoyancy control while navigating, managing air supply and time limits and taking photographs. Task loading can lead to diver stress, resulting in errors and accidents [48]. Reducing task loading is important, especially at deep sites and inside shipwrecks.

Another benefit of wearable cameras is that they do not constrain participants' experience. Further, a hand-held camera may have resulted in divers capturing particular images, or perspectives, because divers were aware of the camera. Instead, it was essential the video recorded natural behaviors, including how time was spent during the dive rather than highlights. A head-mounted camera meant the video data was an accurate reflection of the participants' visual environment. Therefore, using head-mounted video was appropriate for the study.

\section{Study Site}

This article explores video camera observation in diving research, by illustrating the research conducted at Chuuk Lagoon, in Chuuk State, Federated States of Micronesia. Chuuk is north of the equator, approximately 2000 kilometers $(\mathrm{km})$ northeast of Papua New Guinea, 4000 km southeast of the Philippines and $5000 \mathrm{~km}$ southwest of Hawai'i. Chuuk Lagoon is around $64 \mathrm{~km}$ in diameter, covering $2125 \mathrm{~km}^{2}$ and surrounded by a $225 \mathrm{~km}$ long barrier reef. It contains 19 high volcanic islands, 87 small islands and low coral atolls [49-51].

Chuuk was a key strategic advance military base during World War II for Japanese navy vessels, merchant vessels and aircraft, pivotal to Japan's push into the Pacific. Today, in warm, clear tropical waters, lie up to 60 shipwrecks and 13 submerged aircraft (aircraft wrecks), largely intact and with much of the cargo that was in place at the time of the sinking. See Edney [1] (pp. 426-431) for detailed information about the wreck sites. The wrecks are a legacy of World War II aerial bombing raids, primarily 'Operation Hailstone' that occurred on 17 and 18 February 1944 [52-54].

Chuuk Lagoon is a world-renowned wreck diving destination, and since the 1970s, has attracted divers from around the globe. Tourism is important to Chuuk's economy, and the wrecks are Chuuk's major attraction [49,55]. Sustainable diving practices are important for the longevity of this tourism resource and to protect the significant cultural heritage values.

Chuuk was chosen as the study site for several reasons. Divers are attracted to Chuuk for the wreck diving, which offers opportunities, including diving on the outside of 
wrecks or inside the wrecks (wreck penetration) and the opportunity to view artifacts. The environmental quality of the site, including clearwater, is another advantage that enables observation from a distance, enhancing the experience for divers and researchers.

\section{Materials and Methods}

The information reported here formed part of the corresponding author's Ph.D. (referred to here on in as the researcher), seeking to understand wreck diver in-water behavior. The study collected quantitative and qualitative data from the video observations. This article reports on quantitative analysis of the video data gathered by wreck divers using wearable cameras at Chuuk from 8 November to 4 December 2014. The qualitative analysis will be reported elsewhere.

This research was conducted in accordance with the Charles Sturt University Human Research Ethics approval (2012/202), where the study commenced, then under Southern Cross University Human Research Ethics approval (ECN-15-005 and ECN-16-008), where the study was completed. Participation was voluntary, and participants were required to be 18 years of age or older and sign an informed consent form prior to participation. The consent included assigning the copyright of the images to the researcher.

\subsection{Recruitment of Participants}

Participants were recruited using non-probability sampling: convenience, purposive and snowball [56]. Divers staying at Blue Lagoon Dive Resort or visiting Blue Lagoon Dive Shop (on Weno) were approached by the researcher, given an outline of the study and invited to participate. Some people requested involvement in the study after seeing other divers participating. Interested divers were advised the study focus was to determine what wreck divers spent their time doing and looking at while wreck diving. All participants were offered a copy of the video data they collected [10]. More than one video recording per participant was included, consistent with Wiener's [44] method.

\subsection{Cameras}

GoPro ${ }^{\circledR}$ HERO 3+ Silver Edition cameras were used to collect the data. The video resolution setting was $960 \mathrm{p}(1280 \times 960 \mathrm{px})$, with a 4:3 aspect ratio. Frame speed was 60 frames per second, the recommended setting for body-mounted video, and providing the widest field of view (ultra-wide field of view) (GoPro, n.d.). The cameras were mounted on participant's heads using the GoPro ${ }^{\circledR}$ head-mount strap. A thin, soft and flexible neoprene hood with a chin strap was placed over the head-mount straps to prevent the camera from dislodging during entry into the water and throughout the dive (Figure 1).

The researcher gave participants a verbal pre-dive briefing and asked them to conduct their dive as normal. The cameras were switched on prior to entering the water and remained on for the dive duration. The cameras were switched off once the diver returned to the boat on completion of the dive. 


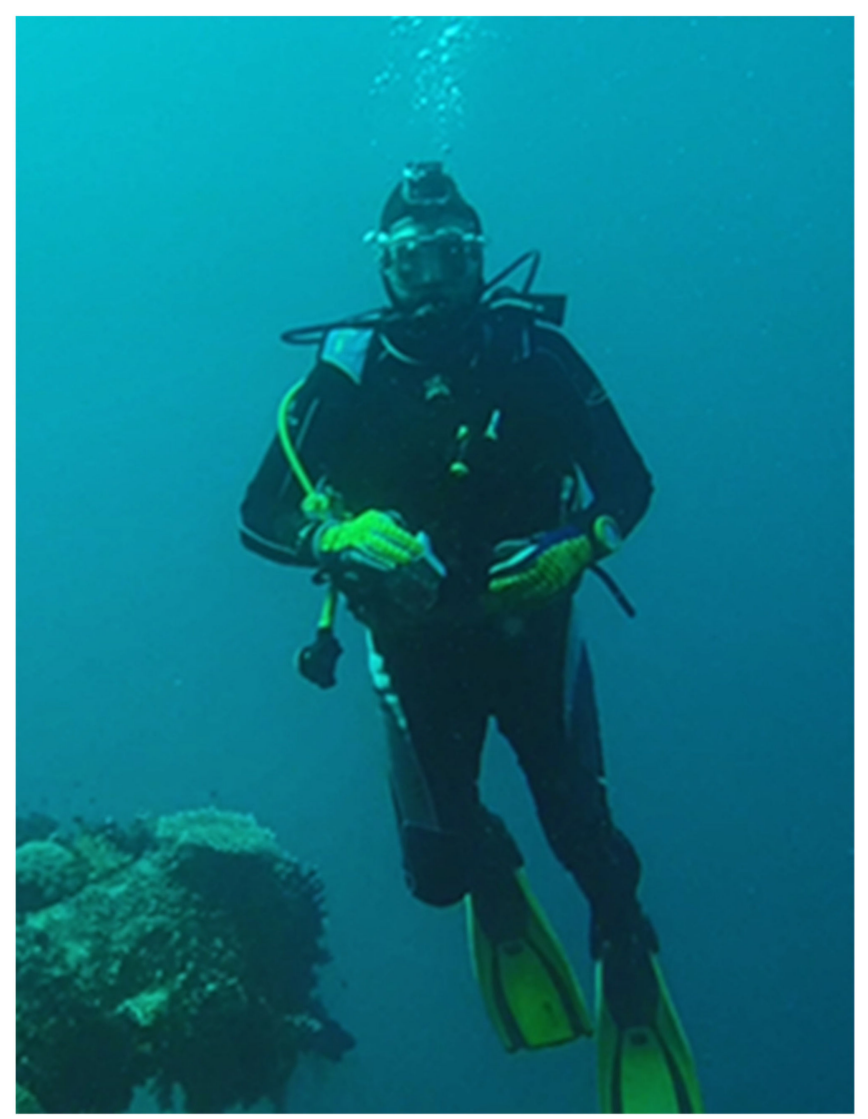

Figure 1. A study participant wearing a head-mounted GoPro ${ }^{\circledR}$ HERO $3^{+}$Silver Edition camera. Image (C) Joanne Edney. Screen shot from the researcher's head-mounted camera.

\subsection{Data Analysis}

On completion of the dive, participants returned cameras to the researcher. The video data for each dive would typically comprise between three and five files. The files were stitched together using Pinnacle Studio 15 video editing software prior to analysis so that each dive observation was contained in a single video file. The video data was recorded as MPEG4 (.mp4) files and retained in this format for analysis. The files were exported to The Observer ${ }^{\circledR}$ XT 12.5, a software package designed for human and animal behavior studies [57] for coding and data analysis.

The behaviors documented and analyzed are described in Table 1. They reflect diver impacts on underwater cultural heritage, such as touching artifacts, activities divers engaged in and what divers spent time looking at. Five behaviors had 'modifiers' attached to further define these behaviors by dividing the behavior into subsets. Behaviors could overlap if this was what was observed (e.g., diver looking at a wreck feature while using a camera). Data were coded for analysis. Diver behaviors were coded and documented from when a diver completed their descent and ceased when the diver commenced their ascent, with one exception (a dive was cut short-Observation 12, Table 2). Here the behavior observation ceased three-quarters of the way through this dive. Each behavior was coded and noted in real-time for the duration of time they occurred, with the exception of 'hand pulling' behavior, which was recorded as 'point' type (one-off) data in Table 1. Point type data is used for behaviors "... without measurable or relevant duration." [57], as is the case for hand pulling. 
Table 1. Coded wreck diver behaviors.

\begin{tabular}{|c|c|c|c|}
\hline Behaviour & Description & Type & Modifiers \\
\hline Inside wreck & $\begin{array}{l}\text { Diver entered an overhead environment. In the holds of } \\
\text { upright ships, this included holds that had the hatch cover } \\
\text { beams in place. }\end{array}$ & Duration & \\
\hline Look at feature of wreck & $\begin{array}{l}\text { Diver was actively engaged in looking at a feature of a wreck, } \\
\text { either some part of the wreck fabric or an artefact * }\end{array}$ & Duration & \\
\hline Look at marine life & Diver was actively engaged in looking at marine life * & Duration & \\
\hline \multirow{6}{*}{ Touch artefact } & \multirow{6}{*}{ Diver deliberately touched an artefact. } & \multirow{6}{*}{ Duration } & Pick up \& inspect \\
\hline & & & Pick up \& move \\
\hline & & & Pick up \& clean \\
\hline & & & Pick up and hold up \\
\hline & & & Pick up and pass to other \\
\hline & & & Clean \\
\hline \multirow{9}{*}{ Use camera } & \multirow{9}{*}{$\begin{array}{l}\text { Diver actively engaged in using some type of camera. No } \\
\text { distinction was made between video and photographs, as } \\
\text { most action cameras are capable of taking both videos and } \\
\text { photographs. Likewise, most other cameras primarily used to } \\
\text { take 'still' photographs also have the capability of taking } \\
\text { video images. In most cases it was not possible to distinguish } \\
\text { between the types of images being captured. Additionally, } \\
\text { many divers with large SLR cameras have both the SLR } \\
\text { camera and an action camera attached to the camera } \\
\text { mounting. }\end{array}$} & \multirow{9}{*}{ Duration } & Artefact \\
\hline & & & Wreck fabric \\
\hline & & & Marine life \\
\hline & & & People \\
\hline & & & People \& wreck \\
\hline & & & People \& artefacts \\
\hline & & & People \& marine life \\
\hline & & & Other \\
\hline & & & Undetermined \\
\hline Hand pulling-wreck & $\begin{array}{l}\text { Diver uses their hands on a wreck to pull (or push) for } \\
\text { propulsion. It is a wreck diving technique used by to move } \\
\text { around wreck sites, as it minimises silting and for moving } \\
\text { against a current because it is more effective than kicking } \\
\text { against a current. }\end{array}$ & Point & \\
\hline Sit on wreck & $\begin{array}{l}\text { Diver sits on wreck or artefact (for example, the armoured } \\
\text { battle tank on the deck of the Nippo Maru). }\end{array}$ & Duration & \\
\hline Stand on wreck & Diver stands on fins (including fin tips) on a wreck. & Duration & \\
\hline Kneel on wreck & Diver kneels on wreck. & Duration & \\
\hline Hold onto wreck & $\begin{array}{l}\text { Diver uses hands or other body part to hold themselves on a } \\
\text { wreck. }\end{array}$ & Duration & \\
\hline Unintentional contact with wreck & \multirow{7}{*}{$\begin{array}{l}\text { Unintentional contacts are those contacts made accidentally. } \\
\text { This often occurs when divers do not have their equipment } \\
\text { secures, due to poor buoyancy and lack of situational } \\
\text { awareness. }\end{array}$} & \multirow{7}{*}{ Duration } & Fins \\
\hline Unintentional contact with artefact & & & Knee \\
\hline \multirow{5}{*}{ Unintentional contact with marine life } & & & Elbow \\
\hline & & & Other body part \\
\hline & & & Tank \\
\hline & & & Gauges \\
\hline & & & $\begin{array}{l}\text { Other equipment (e.g., } \\
\text { light, BCD \#, camera, } \\
\text { accessories) }\end{array}$ \\
\hline Touch marine life & Diver deliberately touches marine life. & Duration & \\
\hline Hand pulling_marine life & $\begin{array}{l}\text { Diver uses their hands on marine life (typically coral) to pull } \\
\text { (or push) themselves for propulsion. }\end{array}$ & Point & \\
\hline
\end{tabular}

* Determined by the main subject visible in the video recordings. ${ }^{\#}$ BCD is an abbreviation for buoyancy control device. Adapted from [1] (p. 117). 
Table 2. Participant-generated data collection details.

\begin{tabular}{|c|c|c|c|c|c|c|c|}
\hline Observation No. & Diver ID & Dive Site & Researcher Present & Gender & Dive Experience Level & Country of Residence & Dive Guide \\
\hline $1^{\#}$ & AUSM5 & Rio De Janeiro Maru & Yes & Male & Less experienced & Australia & DG1 \\
\hline $2^{\#}$ & AUSM1 & Rio De Janeiro Maru & Yes & Male & Less experienced & Australia & DG1 \\
\hline $3^{\#}$ & AUSF2 & Rio De Janeiro Maru & Yes & Female & Moderate $\boldsymbol{V}$ & Australia & DG1 \\
\hline $4^{\#}$ & AUSM4 & San Francisco Maru & Yes & Male & Moderate $\boldsymbol{V}$ & Australia & DG2 \\
\hline 5 & AUSM2 & Yamagiri Maru & Yes & Male & Moderate & Australia & DG2 \\
\hline $6^{\#}$ & AUSM2 & San Francisco Maru & Yes & Male & Moderate $\boldsymbol{V}$ & Australia & DG2 \\
\hline $7^{\#}$ & UKF5 & Gosei Maru & Yes & Female & Moderate & UK & DG1 \\
\hline $8^{\#}$ & UKM6 & Gosei Maru & Yes & Male & Less experienced $\boldsymbol{V}$ & UK & DG1 \\
\hline 9\# & UKM3 & Gosei Maru & Yes & Male & Experienced & UK & DG1 \\
\hline 10 & UKM1 & $I-169$ & No & Male & Experienced ${ }^{*}$ & UK & Not known \\
\hline 11 & USF1 & Kiyosumi Maru & No & Female & Less experienced $\boldsymbol{V}$ & US & Not known \\
\hline 12 & USM2 & Shinkoku Maru & No & Male & Less experienced & US & Not known \\
\hline 13 & USM1 & Shinkoku Maru & Yes & Male & Experienced * & US & DG3 \\
\hline 14 & UKF3 & Fujikawa Maru & No & Female & Experienced $\boldsymbol{V}$ & UK & Not known \\
\hline 15 & UKF2 & Gosei Maru & No & Female & Experienced * & UK & Not known \\
\hline 17 & UKF1 & Sankisan Maru & No & Female & Experienced $^{*}$ & UK & Not known \\
\hline 18 & UKM4 & Yamagiri Maru & No & Male & Experienced $\boldsymbol{V}^{\wedge}$ & UK & Not known \\
\hline 19 & AUSM6 & Nippo Maru & No & Male & Experienced $\boldsymbol{V}^{*}$ & Australia & Not known \\
\hline 20 & AUSM3 & Rio De Janeiro Maru & Yes & Male & Experienced * & Australia & Not known \\
\hline 21 & UKM2 & Kensho Maru & Yes & Male & Experienced $\boldsymbol{V}$ & UK & DG1 + 1 Not known \\
\hline $22 \#$ & AUSM1 & Kiyosumi Maru & Yes & Male & Less experienced & Australia & DG1 \\
\hline $23^{\#}$ & AUSF2 & Kiyosumi Maru & Yes & Female & Moderate & Australia & DG1 \\
\hline
\end{tabular}

Key: $\boldsymbol{V}$ Diver observed using a camera. ^ Diver using a rebreather. ${ }^{*}$ Diver using twin tanks. \# Note: Observations 1, 2 and 3; 4 and 6; 7-9; 22 and 23 occurred on the same dive. (From [1] (p. 216)). 
The focus of the reporting of contact behaviors was on frequencies, as the frequency of contact is more relevant to the level of impact of the action on underwater cultural heritage than the duration. For non-contact behaviors, reporting focuses on the duration of behaviors, as duration gives an indication of the relative importance of these activities to the diver.

\section{Results}

Participant-generated data were collected on 23 dives by 20 divers on 12 shipwrecks (Table 2). Twenty-two of these were complete dives and one partial (three-quarters) dive. One diver, who appeared to be having difficulty with buoyancy and/or dive equipment, removed the camera approximately three-quarters of the way through his dive. Analysis of the dive ended then (Observation 12, Table 2). Three participants, two males and one female, wore the camera on two occasions. The repeat dive was at a different location. A total of 14 hours of participant-generated data were analyzed. Ten participants were observed using their own hand-held cameras. The researcher was present on 14 (61\%) dives where participants collected data (Table 2).

The researcher grouped participants into categories based on information provided on the consent form, observations and discussion with participants. The majority $(65 \%)$ were male, and around one-third (35\%) female. Most were residents of the United Kingdom and Australia, each accounting for 43.5 percent of participants, and 13 percent were from the USA. Almost half ( $48 \%)$ were experienced divers, with the remainder having moderate or lower experience levels (no novice divers) ( $26 \%$ each).

Contact behaviors accounted for almost $15 \%$ of behavior frequencies (Table 3 ). The most frequent contact behavior was hand pulling on wrecks, followed by touching artifacts and holding onto wrecks. Touching marine life and hand pulling on marine life ranked fourth and fifth highest in frequency. The frequencies of sitting and standing on wrecks and unintentional contacts were low. Section 5.1 provides more detail about the breakdown of these behaviors.

Table 3. Summary of scored behaviors.

\begin{tabular}{|c|c|c|c|c|c|c|}
\hline Behaviour & Frequency (n) & $\begin{array}{l}\text { Mean Frequency } \\
\text { (n) }\end{array}$ & $\begin{array}{c}\text { Proportion of } \\
\text { Observed } \\
\text { Behaviour } \\
\text { Frequency (\%) }\end{array}$ & Duration (s) & $\begin{array}{c}\text { Mean } \\
\text { Duration (s) }\end{array}$ & $\begin{array}{c}\text { Proportion of } \\
\text { Observed } \\
\text { Behaviour } \\
\text { Duration (\%) }\end{array}$ \\
\hline \multicolumn{7}{|l|}{ Non-contact behaviours } \\
\hline Look at feature of wreck & 438 & 19.04 & 28.13 & $34,197.77$ & 1486.86 & 57.68 \\
\hline Inside a wreck & 64 & 3.05 & 4.11 & 9231.18 & 439.58 & 15.57 \\
\hline Look at marine life & 535 & 24.32 & 34.36 & $12,038.31$ & 547.20 & 20.31 \\
\hline Use camera & 287 & 28.70 & 18.43 & 2762.85 & 276.29 & 4.66 \\
\hline Total non-contact & 1324 & & 85.03 & $58,230.11$ & & 98.22 \\
\hline \multicolumn{7}{|l|}{ Contact behaviours } \\
\hline Hand pulling_wreck & 82 & 6.31 & 5.27 & & & - \\
\hline Sit on wreck & 1 & 1.00 & 0.07 & 34.50 & 34.50 & 0.06 \\
\hline Stand on wreck & 3 & 1.50 & 0.19 & 16.91 & 8.46 & 0.03 \\
\hline Hold wreck & 46 & 2.88 & 2.96 & 310.59 & 19.41 & 0.52 \\
\hline Touch artefact & 48 & 9.60 & 3.08 & 587.62 & 117.52 & 0.99 \\
\hline Unintentional contact-wreck & 2 & 2.00 & 0.13 & 3.64 & 3.64 & 0.01 \\
\hline Hand pulling-marine life & 24 & 12.00 & 1.54 & & & \\
\hline Touch marine life & 27 & 4.50 & 1.73 & 100.17 & 20.03 & 0.17 \\
\hline Total contact & 233 & & 14.97 & 1053.43 & & 1.78 \\
\hline Total-All behaviours & 1557 & & 100 & $59,283.54$ & & 100 \\
\hline
\end{tabular}

$\mathrm{n}$ is the number of observations (From [1] (p. 219)).

Non-contact behaviors represented the majority ( $>98 \%$ ) of behavior durations (Table 3). Participants spent the highest proportion of their time looking at features of wrecks. This behavior was almost three times higher than looking at marine life, which had the second- 
highest duration. Being inside wrecks was another popular activity, and photography had the lowest duration. A more detailed breakdown of these results is presented in Section 5.2.

\subsection{Analysis of Contact Behavior Frequencies}

The most frequent contact behavior was hand pulling on wrecks. It represented $35.2 \%$ of total contact behaviors and occurred during 13 observations (Table 3). Two participants were primarily responsible for the majority of hand-pulling instances. Frequencies ranged from 1 to 24 per participant per dive, with a mean of 6.31. For more detailed frequency results, see Appendix A, Table A1.

The second most frequent contact behavior was touching artifacts (Figure 2). This behavior represented $20.6 \%$ of contact behaviors, notably recorded during five observations. Frequencies ranged from 5 to 22 , with a mean of 9.6. One participant was responsible for the majority of instances of touching artifacts.

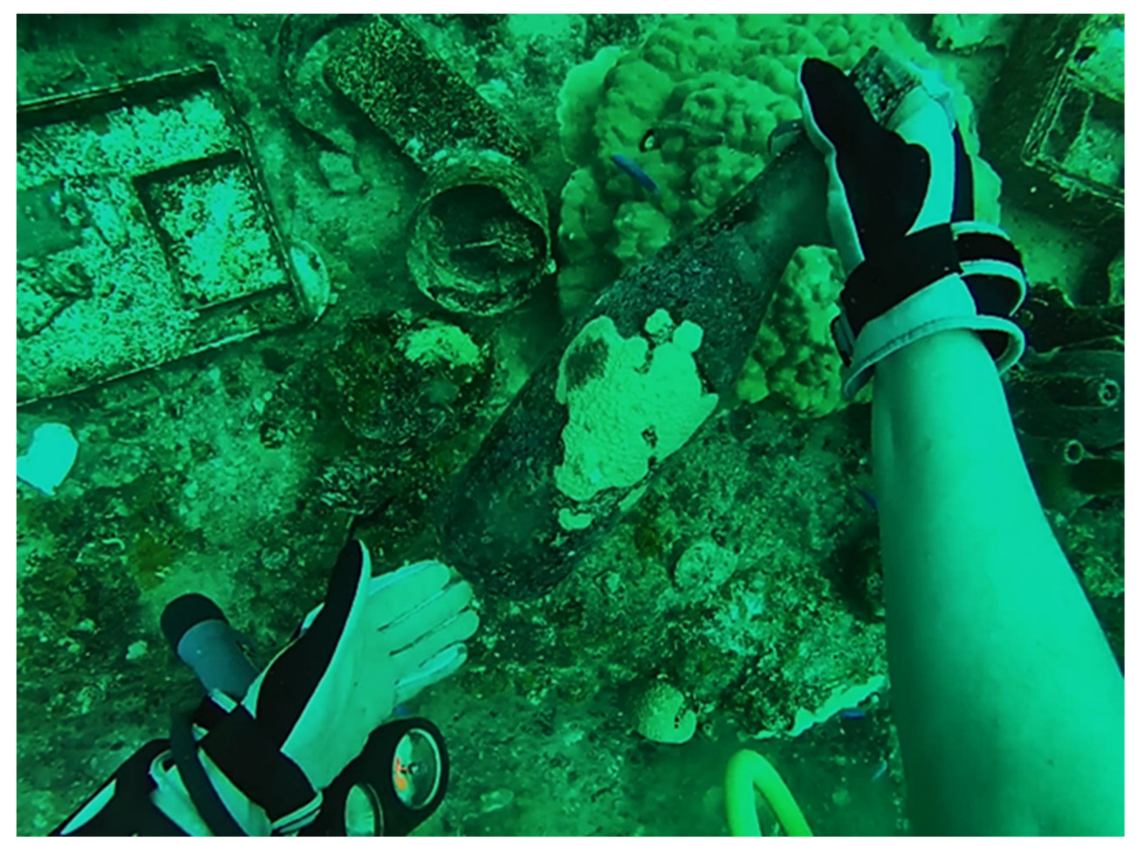

Figure 2. Diver picking up and inspecting a bottle from an artifact cluster on the Kiyosumi Maru. Image (C) Joanne Edney. Screen shot from the participant's head-mounted camera.

Touching artifacts is a critical contact behavior that has the potential for consequential impacts on underwater cultural heritage. It was examined in detail using modifiers to refine the behavior (Table 4). Picking up and inspecting artifacts was the most frequent behavior, markedly more frequent than other touching artifact behaviors. Cleaning, picking up and cleaning, and picking up and passing artifacts to other divers were the next most frequent ways divers touched artifacts.

Holding onto wrecks (Figure 3) was the next most frequent contact behavior (19.7\%) and occurred during 16 observations. Two participants were responsible for the majority of cases of this behavior. Contact with marine life, which included hand pulling on marine life and touching marine life, had frequencies of 24 and 27 and means of 4.5 and 12, respectively. Only two participants hand pulled on marine life, and five touched marine life. One participant was responsible for the majority of contacts with marine life and the majority of remaining contact behaviors, i.e., unintentional contact with wrecks and standing and sitting on wrecks. Two participants were responsible for all instances of these behaviors. Except for one participant, those using cameras had few contacts, four (40\%) had no contact behaviors. Comparing contact frequencies and participant profile variables revealed males (88\%), Australians (84\%) and less experienced divers (56\%) were responsible for most contact behaviors and the majority of touching artifacts instances. 
For more detailed information results on contacts and diver variables, see Appendix A, Tables A2 and A3.

Table 4. Touch artifacts modifier frequencies.

\begin{tabular}{|c|c|c|c|c|c|c|c|c|}
\hline \multirow{3}{*}{ Touch Artefact } & & & den & & & \multirow{3}{*}{$\begin{array}{c}\text { Total } \\
\mathbf{n}\end{array}$} & \multirow{3}{*}{\multicolumn{2}{|c|}{$\begin{array}{c}\text { Total } \\
\%\end{array}$}} \\
\hline & \multicolumn{5}{|c|}{ Observation Number } & & & \\
\hline & 2 & 9 & 19 & 22 & 23 & & & \\
\hline Clean & 1 & 4 & 0 & 2 & 0 & 7 & 14.6 & \\
\hline Pick up \& clean & 1 & 2 & 1 & 2 & 0 & 6 & 12.5 & 27.1 \\
\hline Pick up \& hold up & 0 & 0 & 1 & 0 & 0 & 1 & & 2.1 \\
\hline Pick up \& inspect & 2 & 3 & 3 & 13 & 6 & 27 & & 56.2 \\
\hline Pick up \& move & 1 & 0 & 0 & 5 & 0 & 6 & & 12.5 \\
\hline Pick up \& pass to other diver & 0 & 0 & 1 & 0 & 0 & 1 & & 2.1 \\
\hline Total & 5 & 9 & 6 & 22 & 6 & 48 & & 100 \\
\hline
\end{tabular}

(From Edney [1] (p. 223)).

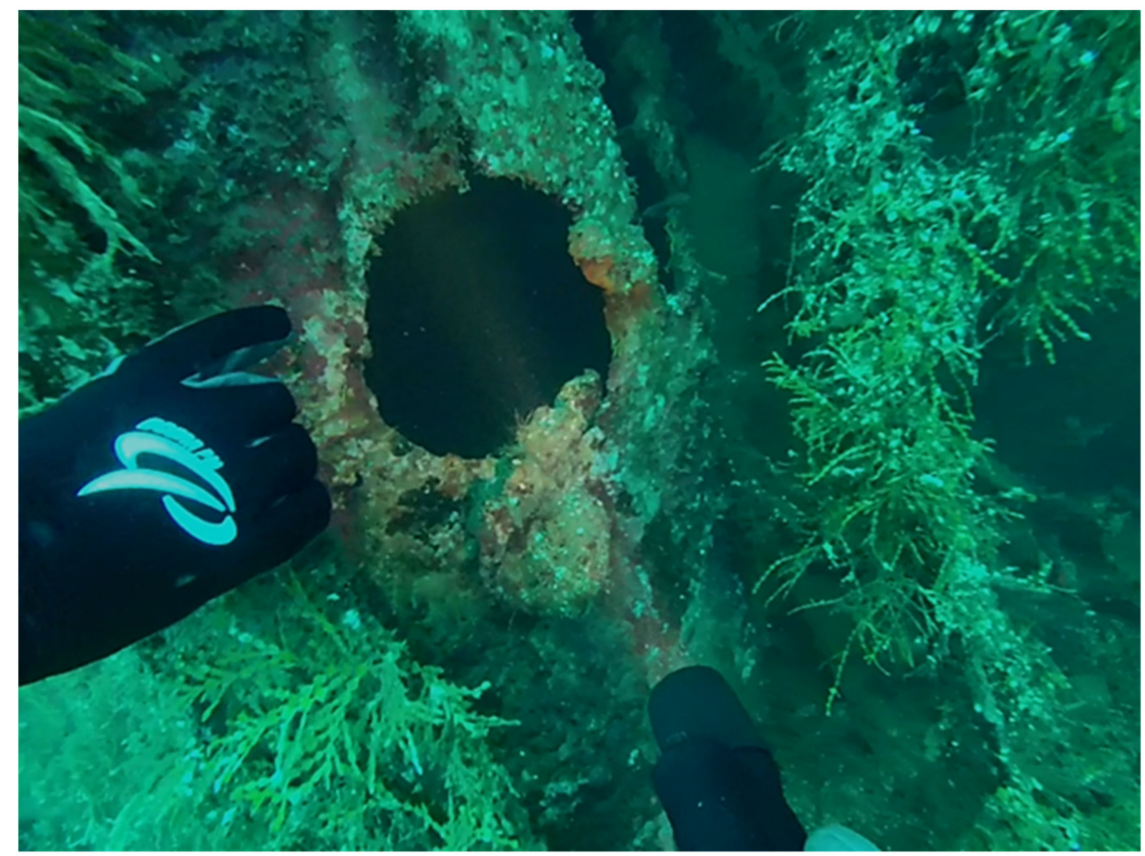

Figure 3. Diver holding onto part of the Kiyosumi Maru to stay steady while looking into a small opening. Image () Joanne Edney. Screen shot from a participant's head-mounted camera.

\subsection{Analysis of Non-Contact Behaviour Durations}

Participants spent greater than half $(57.7 \%)$ of dive time looking at features of wrecks, including artifacts, masts and kingposts, propellers and machinery (Table 3). Viewing marine life was popular $(20.3 \%)$, and considerable dive time (15.6\%) was spent inside wrecks (Table 3). Cargo holds were the most commonly visited parts of wrecks, and divers viewed features such as munitions, gas masks, aircraft, vehicles, bicycles, machinery, crockery, glassware, cooking utensils, tableware, shoes and clothing, beer and sake bottles. For more detailed behavior durations, see Appendix A, Table A4.

Entering superstructures to see the bridge, bathrooms and galleys was popular. Human remains on the wrecks were of interest to divers. Only two participants did not penetrate the wrecks. In one case, the participant was diving the I-169 submarine wreck, which is not possible to enter. The other participant was diving a penetrable wreck, but the guide did not lead the group inside on that occasion, and the divers, therefore, did not enter the wreck. The remaining dive time $(4.7 \%)$ was spent engaged in photography/videography (Figure 4). Popular photography subjects were wrecks (features and artifacts) and marine life (Appendix A, Table A5). 


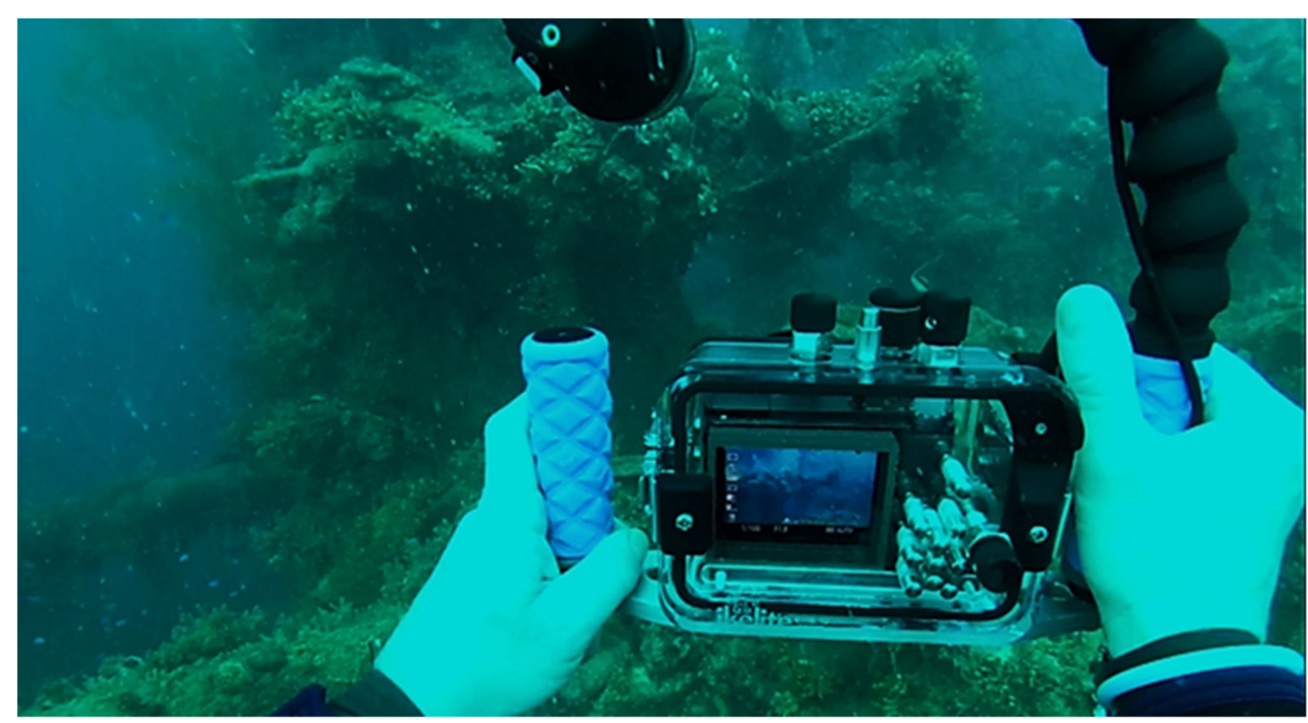

Figure 4. Participant taking a photo of the Kensho Maru bow gun. Image (C) Joanne Edney. Screen shot from participant's head-mounted camera.

\section{Discussion}

The study set out to examine wreck diver behavior in the context of underwater cultural heritage. In achieving its aims, the paper reports one of the first published examples of wearable video cameras to record diver in-water behavior, in addition to introducing participant-generated data and being the first to examine diver non-contact behaviors. The first-person perspective of the data offers unique insight into diver behavior, capturing the participant's environment as they saw it, a different perspective to that obtained from third-person observation. Furthermore, understanding contact and non-contact behaviors provides comprehensive knowledge of diver in-water behaviors. A study of only contact behaviors, for example, provides little insight into the proportion of time spent on other behavior types. Importantly, diver contact behaviors with heritage items affect a site's cultural heritage and tourism values through their negative impacts. Such knowledge is well understood in other fields, such as ecological impact studies of coral reef diving, which highlight how diver profile is associated with environmental damage at heavily visited sites [58].

In the current study, data analysis indicates that contact behaviors represented only a small component of total wreck diver underwater behavior. Nevertheless, understanding those behaviors is crucial, given their potential to negatively impact underwater heritage. Contact behaviors were mostly intentional, indicating they are not attributed to poor diving skills such as buoyancy control. Understanding the source of the behaviors is also beneficial, as it allows site managers better target management. This research found men, Australians, and to a lesser extent, less experienced divers were responsible for the vast majority of contact behaviors.

Hand pulling was the most common contact behavior. This is a wreck diving technique used to minimize silting and move more efficiently against currents. Touching artifacts, mostly to inspect or clean them, was the second most frequent contact behavior (approximately 20\% of contact behaviors) and the one of most concern to heritage managers due to the negative impacts on cultural heritage values. It is, therefore, encouraging that this behavior accounted for such a small proportion of contact behaviors. Any contact with a wreck's fabric or artifacts can accelerate decay, and cleaning removes protective coatings, further accelerating their decay $[3,6]$. When divers search for artifacts and move them, the integrity and the archaeological value of sites are impaired [7]. While there is concern about the impact of these behaviors on the cultural heritage values of these sites, they, importantly, can also diminish the tourism values of the sites, since the appeal to divers is higher when artifacts can be viewed, particularly in-situ $[7,59,60]$. More sustainable use 
of shipwrecks by divers, therefore, has benefits for the protection of underwater cultural heritage, recreation and tourism values of these sites.

Understanding the source of and types of contact behaviors enables heritage managers to target management, particularly education of divers about the causes and consequences of diver contacts with wrecks and their contents. It also allows dive tourism operators who want to use sites more sustainably to target information provided to divers in pre-dive briefings, for example, discouraging the touching of artifacts. Dive tourism operators who depend on wreck sites for their livelihood, such as at Chuuk Lagoon, gain to benefit from encouraging more sustainable use of the sites their businesses depend on.

Examining non-contact behaviors reveals what divers are interested in through the first-person perspective of data. This provides information on diver preferences that should interest site managers and dive operators. Divers in this study, for example, spent much time looking at the wrecks, almost three times as much time as the next most prominent non-contact behavior, viewing marine life. The study site hosts abundant and diverse marine life, yet the wrecks held the divers' attention. The first-person perspective in this study confirms wreck divers' motivation to view shipwrecks and marine life [20,21]. The research also highlighted divers' interest in going inside wrecks, thus confirming the tourism and recreational value of both shipwrecks and marine life for dive tourism operators. This may assist dive tourism operators with the marketing and provision of experiences that appeal most to wreck divers.

In terms of study limitations, the sample size of divers may constrain broad generalizations of the findings. Nevertheless, since this is the first empirical study of actual wreck diver behavior, it provides an important baseline for future wreck diver behavior research. In this sense, it is essential for the emerging field of research regarding sustainable tourism at underwater cultural heritage sites. Although the literature recognizes the observer effect has been overestimated in observation studies using cameras, and the methods used in this study were designed to minimize any observer effect, the possibility that the presence of the camera may have reduced the number of contacts made by participants is acknowledged.

\section{Conclusions}

Two research objectives framed this study: (1) to identify diver contact and noncontact behaviors at shipwrecks in Chuuk Lagoon and (2) to clarify the frequency of diver contact behaviors and durations of non-contact behaviors on shipwrecks in Chuuk Lagoon. Using wearable video cameras, the study achieved its objectives by collecting first-person perspective data to offer insight into what behaviors occurred. The data also advised frequency and duration of behaviors, which clarified the detail of the in-water behavior of this group of wreck divers. As a result, a baseline study is now available on which to build and clarify information for heritage and dive tourism managers at wreck diving sites. Protecting underwater cultural heritage is a key part of managing such sites, and measures taken to guide visitor management are more effective when informed by evidence.

The evidence demonstrates that while the majority of divers behaved responsibly, a few divers contributed to the majority of contacts. Deliberate touching comprised the majority of contacts. When wreck diving, divers are most interested in viewing the wrecks themselves. Other popular activities are viewing marine life and going inside wrecks.

Based on the findings of this research, the following recommendations are made:

1. Site management strategies should target the major sources and types of diver contact behaviors.

2. Education should be provided to divers and dive tourism operators about the causes and consequences of diver contact behaviors and implications to sites (i.e., cultural heritage and recreation/tourism values/economic values to businesses reliant on these sites).

3. Further research into wreck diver in-water behavior.

Further research could use larger samples at different sites to expand on the insights regarding diver behavior reported here. In addition to refining understanding of diver 
behavior per se, qualitative research, such as the use of photo elicitation, could investigate meanings ascribed to diver underwater behavior and wreck diving experiences to further understand the motivations, values and intentions that underlie the observed behaviors.

The findings on diver behavior contribute to informing heritage and tourism management decisions and provide a baseline for future studies. Methodologically, the study demonstrates the power of a research method of observing divers and other recreationists, namely, first-person camera-based data collections. This is particularly valuable for researching recreationalists who are operating in confined spaces, such as caves, canyons and, in this case, shipwrecks.

Author Contributions: Conceptualization, J.E., K.D. and W.E.B.; methodology, J.E, K.D. and W.E.B.; formal analysis, J.E.; investigation, J.E.; resources, J.E.; data curation, J.E.; writing—original draft preparation, J.E., K.D. and W.E.B.; writing-review and editing, J.E., K.D. and W.E.B.; visualization, J.E.; supervision, W.E.B. and K.D.; project administration, J.E.; funding acquisition, J.E. All authors have read and agreed to the published version of the manuscript.

Funding: The fieldwork for this research was funded by the Women Divers Hall of Fame Cecelia Connelly Memorial Graduate Scholarship in Underwater Archaeology and a Charles Sturt University grant for travel and equipment. The analysis was supported by a Southern Cross University grant to purchase the behavioral analysis software. The research was also supported by an Australian Postgraduate Award/Australian Government Research Training Program Scholarship.

Institutional Review Board Statement: The study was conducted according to the guidelines of the Declaration of Helsinki, and approved by the Charles Sturt University Human Research Ethics Committee (2012/202) and Southern Cross University Human Research Ethics Committee (ECN-15005 and ECN-16-008).

Informed Consent Statement: Informed consent was obtained from all subjects involved in the study.

Data Availability Statement: Ethics approvals do not permit sharing of the raw data. All processed data supporting the results are included in the manuscript.

Acknowledgments: We would like to thank all of the divers who gave their time to participate in the video observations. Without their participation, this research would not have been possible. Special thanks to Gradvin Aisek and the Aisek family for graciously allowing me to conduct the fieldwork for this study from their Blue Lagoon Dive Shop and Blue Lagoon Dive Resort. I greatly support the willingness of the Aisek family to support the research, and to Dianne Strong for her role in facilitating it. Thanks also to Jonathon Howard and Dirk Spennemann for their input into the design of this study.

Conflicts of Interest: The authors declare no conflict of interest. 


\section{Appendix A}

Table A1. Frequency of participant behaviors.

\begin{tabular}{|c|c|c|c|c|c|c|c|c|c|c|c|c|c|c|c|c|c|c|c|c|c|c|c|c|c|}
\hline \multirow{3}{*}{ Behaviour } & \multicolumn{23}{|c|}{ Frequency (n) } & \multirow{3}{*}{ Total } & \multirow{3}{*}{ Mean } \\
\hline & \multicolumn{23}{|c|}{ Observation Number } & & \\
\hline & 1 & 2 & 3 & 4 & 5 & 6 & 7 & 8 & 9 & 10 & 11 & 12 & 13 & 14 & 15 & 16 & 17 & 18 & 19 & 20 & 21 & 22 & 23 & & \\
\hline Look at feature of wreck & 12 & 19 & 25 & 9 & 17 & 5 & 28 & 36 & 23 & 16 & 16 & 10 & 35 & 20 & 32 & 12 & 22 & 11 & 8 & 32 & 20 & 14 & 16 & 438 & 19.04 \\
\hline Inside a wreck & 3 & 3 & 4 & 1 & 3 & 1 & 3 & 2 & 7 & 0 & 4 & 1 & 4 & 3 & 3 & 2 & 2 & 6 & 2 & 4 & 0 & 3 & 3 & 64 & 3.05 \\
\hline Look at marine life & 1 & 16 & 14 & 0 & 19 & 2 & 44 & 22 & 58 & 43 & 33 & 10 & 38 & 19 & 62 & 11 & 37 & 20 & 1 & 11 & 29 & 18 & 27 & 535 & 24.32 \\
\hline Use camera & 0 & 0 & 20 & 25 & 0 & 11 & 0 & 49 & 0 & 0 & 13 & 0 & 0 & 33 & 0 & 74 & 0 & 1 & 1 & 0 & 60 & 0 & 0 & 287 & 28.70 \\
\hline Non-contact behaviour totals & 16 & 38 & 63 & 35 & 39 & 19 & 75 & 109 & 88 & 59 & 66 & 21 & 77 & 75 & 97 & 99 & 61 & 38 & 12 & 47 & 109 & 35 & 46 & 1324 & \\
\hline Hand pulling-wreck & 3 & 21 & 0 & 3 & 5 & 0 & 1 & 1 & 3 & 0 & 0 & 0 & 0 & 1 & 0 & 0 & 0 & 4 & 24 & 1 & 0 & 14 & 1 & 82 & 6.31 \\
\hline Sit on wreck & 0 & 0 & 0 & 0 & 0 & 0 & 0 & 0 & 0 & 0 & 0 & 0 & 0 & 0 & 0 & 0 & 0 & 0 & 1 & 0 & 0 & 0 & 0 & 1 & 1.00 \\
\hline Stand on wreck & 0 & 0 & 0 & 0 & 0 & 0 & 0 & 0 & 0 & 0 & 0 & 0 & 0 & 0 & 0 & 0 & 0 & 0 & 1 & 0 & 0 & 2 & 0 & 3 & 1.50 \\
\hline Hold onto wreck & 0 & 8 & 0 & 3 & 1 & 0 & 2 & 1 & 1 & 1 & 0 & 0 & 2 & 3 & 0 & 0 & 1 & 2 & 3 & 1 & 1 & 11 & 5 & 46 & 2.88 \\
\hline Touch artefact & 0 & 5 & 0 & 0 & 0 & 0 & 0 & 0 & 9 & 0 & 0 & 0 & 0 & 0 & 0 & 0 & 0 & 0 & 6 & 0 & 0 & 22 & 6 & 48 & 9.60 \\
\hline Unintentional contact with wreck & 0 & 0 & 0 & 0 & 0 & 0 & 0 & 0 & 0 & 0 & 0 & 0 & 0 & 0 & 0 & 0 & 0 & 0 & 0 & 0 & 0 & 2 & 0 & 2 & 2.00 \\
\hline Hand pulling-marine life & 0 & 0 & 0 & 0 & 0 & 0 & 0 & 0 & 0 & 0 & 0 & 0 & 0 & 0 & 0 & 0 & 0 & 0 & 0 & 0 & 0 & 21 & 3 & 24 & 12.00 \\
\hline Touch marine life & 0 & 4 & 0 & 0 & 1 & 0 & 0 & 0 & 2 & 1 & 0 & 0 & 0 & 0 & 0 & 0 & 0 & 0 & 0 & 0 & 0 & 15 & 4 & 27 & 4.50 \\
\hline Contact behaviour totals & 3 & 38 & 0 & 6 & 7 & 0 & 3 & 2 & 15 & 2 & 0 & 0 & 2 & 4 & 0 & 0 & 1 & 6 & 35 & 2 & 1 & 87 & 19 & 233 & \\
\hline Total-All behaviours & 19 & 76 & 63 & 41 & 46 & 19 & 78 & 111 & 103 & 61 & 66 & 21 & 79 & 79 & 97 & 99 & 62 & 44 & 47 & 49 & 110 & 122 & 65 & 1557 & \\
\hline
\end{tabular}

Note: Observations 2 and 22, 3 and 23, and 5 and 6 were recorded by the same divers—refer to Table 2 above for more details. (From [1] (p. 221). 
Table A2. Contact behavior frequencies by diver profile variables.

\begin{tabular}{|c|c|c|c|c|c|c|c|c|c|c|c|c|c|c|c|c|c|c|c|c|}
\hline \multirow{3}{*}{$\begin{array}{l}\text { Diver Profile } \\
\text { Variable }\end{array}$} & \multicolumn{20}{|c|}{ Frequencies } \\
\hline & \multicolumn{2}{|c|}{ Observations } & \multicolumn{2}{|c|}{$\begin{array}{c}\text { Hand } \\
\text { Pull-Wreck }\end{array}$} & \multicolumn{2}{|c|}{$\begin{array}{c}\text { Touch } \\
\text { Artefacts }\end{array}$} & \multicolumn{2}{|c|}{$\begin{array}{l}\text { Hold onto } \\
\text { Wreck }\end{array}$} & \multicolumn{2}{|c|}{$\begin{array}{l}\text { Stand on } \\
\text { Wreck }\end{array}$} & \multicolumn{2}{|c|}{ Sit on Wreck } & \multicolumn{2}{|c|}{$\begin{array}{l}\text { Unintentional } \\
\text { Contact with } \\
\text { Wreck }\end{array}$} & \multicolumn{2}{|c|}{$\begin{array}{c}\text { Touch Marine } \\
\text { Life }\end{array}$} & \multicolumn{2}{|c|}{$\begin{array}{c}\text { Hand } \\
\text { Pull-Marine } \\
\text { Life }\end{array}$} & \multicolumn{2}{|c|}{ Total } \\
\hline & $\mathbf{n}$ & $\%$ & $\mathbf{n}$ & $\%$ & $\mathbf{n}$ & $\%$ & $\mathbf{n}$ & $\%$ & $\mathbf{n}$ & $\%$ & $\mathbf{n}$ & $\%$ & $\mathbf{n}$ & $\%$ & $\mathbf{n}$ & $\%$ & $\mathbf{n}$ & $\%$ & $\mathbf{n}$ & $\%$ \\
\hline \multicolumn{21}{|l|}{ Gender } \\
\hline Male & 15 & 65 & 79 & 96 & 42 & 88 & 35 & 76 & 3 & 100 & 1 & 100 & 2 & 100 & 23 & 85 & 21 & 88 & 206 & 88 \\
\hline Female & 8 & 35 & 3 & 4 & 6 & 12 & 11 & 24 & 0 & 0 & 0 & 0 & 0 & 0 & 4 & 15 & 3 & 12 & 27 & 12 \\
\hline Total & 23 & 100 & 82 & 100 & 48 & 100 & 46 & 100 & 3 & 100 & 1 & 100 & 2 & 100 & 27 & 100 & 24 & 100 & 233 & 100 \\
\hline \multicolumn{21}{|l|}{ Country of residence } \\
\hline United Kingdom & 10 & 44 & 10 & 12 & 9 & 19 & 12 & 26 & 0 & 0 & 0 & 0 & 0 & 0 & 3 & 11 & 0 & 0 & 34 & 15 \\
\hline United States & 3 & 12 & 0 & 0 & 0 & 0 & 2 & 4 & 0 & 0 & 0 & 0 & 0 & 0 & 0 & 0 & 0 & 0 & 2 & 1 \\
\hline Total & 23 & 100 & 82 & 100 & 48 & 100 & 46 & 100 & 3 & 100 & 1 & 100 & 2 & 100 & 27 & 100 & 24 & 100 & 233 & 100 \\
\hline \multicolumn{21}{|l|}{ Dive experience level } \\
\hline Less experienced & 6 & 26 & 39 & 48 & 27 & 56 & 20 & 43 & 2 & 67 & 0 & 0 & 2 & 100 & 19 & 70 & 21 & 88 & 130 & 56 \\
\hline Moderate & 6 & 26 & 10 & 12 & 6 & 13 & 11 & 24 & 0 & 0 & 0 & 0 & 0 & 0 & 5 & 19 & 3 & 12 & 35 & 15 \\
\hline Experienced & 11 & 48 & 33 & 40 & 15 & 31 & 15 & 33 & 1 & 33 & 1 & 100 & 0 & 0 & 3 & 11 & 0 & 0 & 68 & 29 \\
\hline Total & 23 & 100 & 82 & 100 & 48 & 100 & 46 & 100 & 3 & 100 & 1 & 100 & 2 & 100 & 27 & 100 & 24 & 100 & 233 & 100 \\
\hline
\end{tabular}

(From [1] (p. 230).

Table A3. Contact behavior frequency proportions by diver profile variables.

\begin{tabular}{|c|c|c|c|c|c|c|c|c|}
\hline \multirow{3}{*}{ Behaviour } & \multicolumn{8}{|c|}{ Frequency Percent } \\
\hline & \multicolumn{2}{|c|}{ Gender } & \multicolumn{3}{|c|}{ Country of Residence } & \multicolumn{3}{|c|}{ Dive Experience Level } \\
\hline & Male & Female & Australia & United Kingdom & United States & Less & Moderate & Experienced \\
\hline Hand pull-wreck & 38.3 & 11.1 & 36.6 & 29.4 & 0 & 30 & 28.6 & 48.4 \\
\hline Touch artefacts & 20.4 & 22.2 & 19.8 & 26.5 & 0 & 20.8 & 17.1 & 22.1 \\
\hline Hold onto wreck & 17 & 40.8 & 16.2 & 35.3 & 100 & 15.4 & 31.4 & 22.1 \\
\hline Stand on wreck & 1.5 & 0 & 1.5 & 0 & 0 & 1.5 & 0 & 1.5 \\
\hline Sit on wreck & 0.5 & 0 & 0.5 & 0 & 0 & 0 & 0 & 1.5 \\
\hline Unintentional contact-wreck & 1 & 0 & 1 & 0 & 0 & 1.5 & 0 & 0 \\
\hline Touch marine life & 11.1 & 14.8 & 12.2 & 8.8 & 0 & 14.6 & 14.3 & 4.4 \\
\hline Hand pull-marine life & 10.2 & 11.1 & 12.2 & 0 & 0 & 16.2 & 8.6 & 0 \\
\hline
\end{tabular}


Table A4. Durations of participant behavior.

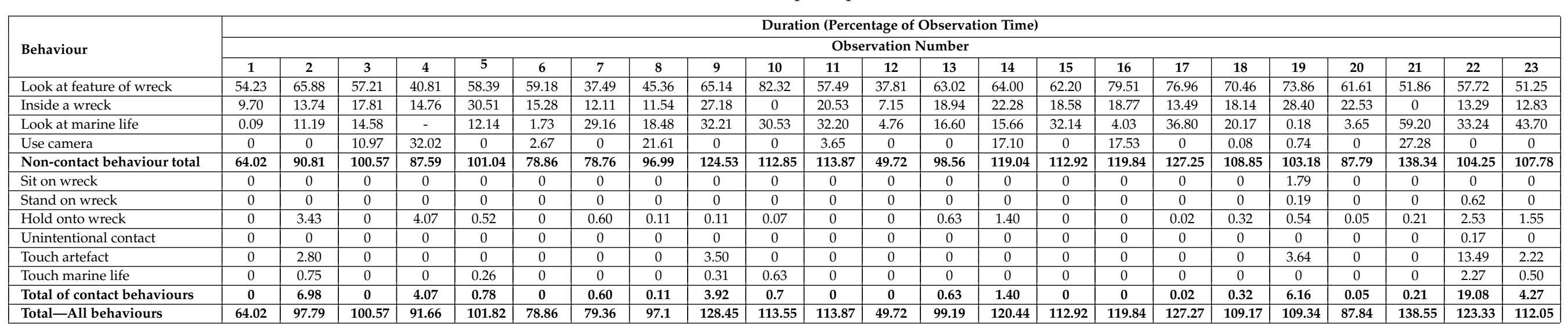

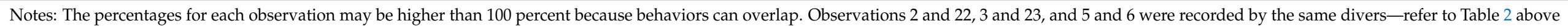

for more details. There is no duration data for hand pulling—wreck and marine life because these behaviors are point event data. (From [1] (p. 226)). 
Table A5. Use camera modifiers.

\begin{tabular}{|c|c|c|c|c|c|c|c|c|c|c|c|c|}
\hline \multirow{3}{*}{ Use Camera Modifiers } & \multicolumn{10}{|c|}{ Frequencies (n) } & \multirow{3}{*}{$\begin{array}{c}\text { Total } \\
\mathbf{n}\end{array}$} & \multirow{3}{*}{$\begin{array}{c}\text { Total } \\
\%\end{array}$} \\
\hline & \multicolumn{10}{|c|}{ Observation Number } & & \\
\hline & 3 & 4 & 6 & 8 & 11 & 14 & 16 & 18 & 19 & 21 & & \\
\hline Artefacts & 3 & 11 & 2 & 7 & 6 & 10 & 4 & 0 & 0 & 1 & 44 & 15.3 \\
\hline People \& artefacts & 0 & 1 & 1 & 3 & 0 & 1 & 0 & 0 & 0 & 0 & 6 & 2.1 \\
\hline Wreck fabric & 8 & 6 & 4 & 11 & 2 & 12 & 31 & 0 & 0 & 11 & 85 & 29.6 \\
\hline People \& wreck & 3 & 7 & 4 & 10 & 3 & 1 & 34 & 0 & 1 & 0 & 63 & 22.0 \\
\hline Marine life & 4 & 0 & 0 & 18 & 2 & 9 & 5 & 1 & 0 & 48 & 87 & 30.3 \\
\hline Undetermined & 2 & 0 & 0 & 0 & 0 & 0 & 0 & 0 & 0 & 0 & 2 & 0.7 \\
\hline Total-Use camera & 20 & 25 & 11 & 49 & 13 & 33 & 74 & 1 & 1 & 60 & 287 & 100 \\
\hline
\end{tabular}

From [1] (p. 223).

\section{References}

1. Edney, J. Lust for Rust: Wreck Divers and the Management of Underwater Cultural Heritage. Ph.D. Thesis, School of Environment, Science and Engineering, Southern Cross University, Lismore, Australia, 2018.

2. Edney, J. A framework for managing diver impacts on historic shipwrecks. J. Marit. Archaeol. 2016, 11, 271-297. [CrossRef]

3. MacLeod, I.D.; Richards, V.L. In situ conservation surveys of iron shipwrecks in Chuuk Lagoon and the impact of human intervention. AICCM Bull. 2011, 32, 106-122. [CrossRef]

4. Kenderdine, S. Culture and heritage: Shipwrecks and associated objects. In State of the Environment Technical Paper Series (Natural and Cultural Heritage); Department of the Environment: Canberra, Australia, 1997.

5. Nutley, D. Underwater cultural heritage management. In Issues in Management Archaeology; Smith, L., Clarke, A., Eds.; Anthropology Museum, The University of Queensland: Brisbane, Australia, 1996.

6. Jeffery, B. A CRM approach in investigating the submerged World War II sites in Chuuk Lagoon. Micrones. J. Humanit. Soc. Sci. 2006, 5, 137-155.

7. Delgado, J.P. The value of shipwrecks. In Historic Shipwrecks: Issues in Management; Waldron, J.M., Ed.; Partners for Liveable Places and National Trust: Washington, DC, USA, 1988; pp. 1-10.

8. Vrana, K.J.; Mahoney, E.M. Impacts on underwater cultural resources: Diagnosing change and prescribing solutions. In Underwater Archaeology: Society for Historical Archaeology Conference; The Society for Historical Archaeology: Washington, DC, USA, 1995.

9. Scott-Ireton, D. Preserves, Parks and Trails: Strategy and Response in Maritime Cultural Resource Management. Ph.D. Thesis, Department of Anthropology Florida State University, Tallahassee, FL, USA, 2005.

10. Edney, J.; Boyd, W.E. Diving under the radar: Divers and submerged aircraft. J. Herit. Tour. 2021, 16, 100-117. [CrossRef]

11. Dimmock, K.; Cummins, T. History of scuba diving tourism. In Scuba Diving Tourism; Musa, G., Dimmock, K., Eds.; Routledge: Abington, UK, 2013; pp. 14-28.

12. Andy, L.; Lee, R.-Y.; Tzeng, G.-H. Characteristics of Professional Scuba Dive Guides. Tour. Mar. Environ. $2014,10,85-100$. [CrossRef]

13. Klint, L.M.; Jiang, M.; Law, A.; DeLacy, T.; Filep, S.; Calgaro, E.; Dominey-Howes, D.; Harrison, D. Dive tourism in Luganville, Vanuatu: Shocks, stressors, and vulnerability to climate change. Tour. Mar. Environ. 2012, 8, 91-109. [CrossRef]

14. Edney, J. Human dimensions of wreck diving and management: Case studies from Australia and Micronesia. Tour. Mar. Environ. 2017, 12, 169-182. [CrossRef]

15. Cater, C. Perceptions of and interactions with marine environments: Diving attractions from Great Whites to pygmy seahorses. In New Frontiers in Marine Tourism: Diving Experiences, Sustainability, Management; Garrod, B., Gössling, S., Eds.; Elsevier Ltd.: Amsterdam, The Netherlands, 2008; pp. 49-64.

16. Kaoru, Y.; Hoagland, P. The value of historic shipwrecks: Conflicts and management. Coast. Manag. 1994, 22, 195-213. [CrossRef]

17. Edney, J. Impacts of recreational scuba diving on shipwrecks in Australia and the Pacific: A review. Micrones. J. Humanit. Soc. Sci. 2006, 5, 201-233.

18. Holecek, D.F.; Lothrop, S.J. Attitudes of a Scuba Diving Population Concerning Government Regulation of Underwater Resources; Michigan State University: East Lansing, MI, USA, 1980.

19. Holecek, D.F.; Lothrop, S.J. Shipwreck vs. Nonshipwreck Scuba Divers: Characteristics, Behavior, and Expenditure Patterns; Michigan Sea Grant Publications Office: Ann Arbor, MI, USA, 1980.

20. Edney, J. What Do Wreck Divers Want? Understanding Australian Wreck Divers; Diving into Archaeology, Office of Environment and Heritage: Parramatta, Australia, 23 May 2012.

21. Edney, J. Understanding wreck divers: Case studies from Australia and Chuuk Lagoon. In Proceedings of the Asia-Pacific Regional Conference on Underwater Cultural Heritage, Manila, Philippines, 8-12 November 2011.

22. Edney, J. Diver characteristics, motivations and attitudes: Chuuk Lagoon. Tour. Mar. Environ. 2012, 8, 7-18. [CrossRef]

23. Edney, J.; Spennemann, D.H.R. Can artificial reefs reduce impacts on historic shipwrecks? Perceptions and motivations held by wreck divers. J. Australas. Inst. Marit. Archaeol. 2014, 38, 93-110.

24. Edney, J.; Spennemann, D.H.R. Can Artificial Reef Wrecks Reduce Diver Impacts on Shipwrecks? The Management Dimension. J. Marit. Archaeol. 2015, 10, 141-157. [CrossRef] 
25. Baumeister, R.F.; Vohs, K.D.; Funder, D.C. Psychology as the Science of Self-Reports and Finger Movements: Whatever Happened to Actual Behavior? Perspect. Psychol. Sci. 2007, 2, 396-403. [CrossRef] [PubMed]

26. Kelly, P.; Doherty, A.; Mizdrak, A.; Marshall, S.; Kerr, J.; Legge, A.; Godbole, S.; Badland, H.; Oliver, M.; Foster, C. High group level validity but high random error of a self-report travel diary, as assessed by wearable cameras. J. Transp. Health 2014, 1, 190-201. [CrossRef]

27. Prosser, J.; Loxley, A. ESRC National Centre for Research Methods review paper: Introducing visual methods. In NCRM Review Papers; National Centre for Research Methods: Southampton, UK, 2008.

28. Campos, J.L.A.; Da Silva, T.C.; Albuquerque, U.P. Participant Observation and Field Journal: When to Use and How to Analyze. In Methods and Techniques in Ethnobiology and Ethnoecology; Springer: New York, NY, USA, 2019; pp. 25-34.

29. Nordstrom, J. Participant Observations in Community Language Schools in Australia. In Researching Education for Social Justice in Multilingual Settings: Ethnographic Principles in Qualitative Research; Conteh, J., Ed.; Bloomsbury Publishing: London, UK, 2017; p. 213.

30. Reitman, D.; Grimes, M.; Allan, C.C.; Pyle, K. Participant observations: Considerations and applications across home, outpatient, and school contexts. In Proceedings of the 52nd Annual Meeting of the Association of Behavior and Cognitive Therapies, Washington, DC, USA, 15-18 November 2018.

31. Adair, J.G. The Hawthorne Effect: A Reconsideration of the Methodological Artifact. J. Appl. Psychol. 1984, 69, 334-345. [CrossRef]

32. Babbie, E. The Basics of Social Research, 5th ed.; Belmont, C.A., Ed.; Cengage Learning: Wadsworth, OH, USA, 2011.

33. Angrosino, M.A.; de Perez, K.M.A. Rethinking observation. In Handbook of Qualitative Research; Denzin, N.K., Lincoln, Y.S., Eds.; Sage Publications Inc.: Thousand Oaks, CA, USA, 2000; pp. 673-702.

34. Chalfen, R. 'Your panopticon or mine?' Incorporating wearable technology's Glass and GoPro into visual social science. Vis. Stud. 2014, 29, 299-310. [CrossRef]

35. Heath, C.; Luff, P. Video and the analysis of work and interaction. In The Sage Handbook of Social Research Methods; Alasuutari, P., Bickman, L., Brannen, J., Eds.; Sage Publication Ltd.: London, UK, 2008; pp. 493-505.

36. Prosser, J. Visual methodology: Toward a more seeing research. In The SAGE Handbook of Qualitative Research; Denzin, N.K., Lincoln, Y.S., Eds.; SAGE Publications Inc.: Los Angeles, CA, USA, 2011; pp. 479-495.

37. Brown, K.M.; Dilley, R.; Marshall, K. Using a Head-Mounted Video Camera to Understand Social Worlds and Experiences. Sociol. Res. Online 2008, 13, 31-40. [CrossRef]

38. Kelly, P.; Marshall, S.J.; Badland, H.; Kerr, J.; Oliver, M.; Doherty, A.R.; Foster, C. An Ethical Framework for Automated, Wearable Cameras in Health Behavior Research. Am. J. Prev. Med. 2013, 44, 314-319. [CrossRef] [PubMed]

39. Kinsley, K.M.; Schoonover, D.; Spitler, J. GoPro as an ethnographic tool: A wayfinding study in an academic library. J. Access Serv. 2016, 13, 7-23. [CrossRef]

40. Lahlou, S. How can we capture the subject's perspective? An evidence-based approach for the social scientist. Soc. Sci. Inf. 2011, 50, 607-655. [CrossRef]

41. Mausner, C. Capturing the hike experience on video: A new methodology for studying human transactions with nature. In Proceedings of the Northeastern Recreation Research Symposium, Bolton Landing, NY, USA, 10-12 April 2005.

42. Yoshida, H.; Smith, L.B. What's in View for Toddlers? Using a Head Camera to Study Visual Experience. Infancy 2008, 13, 229-248. [CrossRef] [PubMed]

43. Browning, D.; Benckdorff, P.; Bidwell, N. Capturing visitor experience using egocentric POV video. In Proceedings of the Voices in Tourism Development: Creating Spaces for Tacit Knowledge and Innovation, Breda, The Netherlands, 3-5 November 2008.

44. Wiener, C.S. Understanding Spinner Dolphin Marine Tourism in Hawai'i: A Social Approach to Assessing Underwater Interactions. Ph.D. Thesis, Environmental Studies, York University, Toronto, ON, Canada, 2016.

45. Pringle, M.; Stewart-Evans, C. Does awareness of being video recorded affect doctors' consultation behaviour? Br. J. Gen. Pract. 1990, 40, 455-458.

46. Paradis, E.; Sutkin, G. Beyond a good story: From Hawthorne Effect to reactivity in health professions education research. Med. Educ. 2017, 51, 31-39. [CrossRef] [PubMed]

47. Lee, C.; Bahn, S.; Kim, G.W.; Yun, M.H. Performance comparison of manual and touch interface using video-based behavior analysis. J. Ergon. Soc. Korea 2010, 29, 655-659. [CrossRef]

48. Gilliam, B.; von Maier, R. Deep Diving: An Advanced Guide to Physiology, Procedures and Systems; Watersport Publishing Inc.: San Diego, CA, USA, 1992.

49. Jeffery, B. World War II shipwrecks in Truk Lagoon: The role of interest groups. CRM J. 2004, 1, 51-67.

50. Jeffery, W. War Graves, Munition Dumps and Pleasure Grounds: A Post-Colonial Perspective of Chuuk Lagoon's Submerged World War II Sites. Ph.D. Thesis, School of Arts, Education and Social Sciences, James Cook University, Douglas, Australia, 2007.

51. Smith, W.J. The place of rural, remote and least-wealthy small islands in international water development: The nexus of geography-technology sustainability in Chuuk State, Federated States of Micronesia. Geogr. J. 2008, 174, 251-268. [CrossRef]

52. Craib, J.L. Truk Archaeology: An intensive archaeological survey of Pwene Village, Dublon, Truk State, Federated States of Micronesia. In Micronesian Resources Study; Look, D.W., Ed.; US National Park Service: San Francisco, CA, USA, 1997.

53. Hezel, F.X.; Graham, C. Truk's underwater museum: A report on the sunken Japanese ships, Federated States of Micronesia. In Micronesian Resources Study; Pepin-Donat, M., Look, D., Eds.; US National Park Service: San Francisco, CA, USA, 1997. 
54. Jeffery, B. World War II underwater cultural heritage sites in Truk Lagoon: Considering a case for World Heritage listing. Int. J. Naut. Archaeol. 2004, 33, 106-121. [CrossRef]

55. Bailey, D.E. World War II Wrecks of the Truk Lagoon; North Valley Diver Publications: Redding, CA, USA, 2000.

56. De Vaus, D. Surveys in Social Research, 6th ed.; Allen \& Unwin: Sydney, Australia, 2014.

57. Grieco, F.; Loijens, L.; Krips, O.; Zimmerman, P.; Spink, A. Reference Manual: The Observer XT Version 12.5; Noldus Information Technology: Wageningen, The Netherlands, 2015.

58. Giglio, V.J.; Luiz, O.J.; Ferreira, C.E. Ecological impacts and management strategies for recreational diving: A review. J. Environ. Manag. 2020, 256, 1-9. [CrossRef]

59. Bower, R.; Smith, T. SS Catterthun (1881-1895): Case for Declaration as an Historic Shipwreck; Heritage Branch, Department of Planning: Sydney, Australia, 1991.

60. Hosty, K. Historic shipwreck legislation and the Australian diver. Past, present and future. J. Aust. Inst. Marit. Archaeol. 1987, 11, 21-25. 